\title{
Responding to Reggio Emilia: Researching with Materials to Cultivate an Ecology of Practice in Early Childhood Education
}

\author{
Kelly Boucher
}

Kelly Boucher is an education consultant and academic based in regional Victoria, Australia. An arts specialist with broad and varied experience teaching in both the arts and education sectors, her research primarily focuses on children's relations with materials in early childhood and questions how materials might be seen as doing significant pedagogical work with children. In her own studiobased arts practice she engages with materials and processes typically used in early childhood settings in order to "think materials otherwise" and generate nontypical material questionings of/with the world. Kelly also works across early childhood services as a pedagogical facilitator to active critical dialogue with/in theory and practice. Email: kellyboucherarts@gmail.com

This article traces an artist/pedagogue's work with materials, children, and educators in response to a Reggio Emilia study tour experience and how this work was understood, positioned, and activated at a children's service in Australia. Through situated, collaborative, everyday materials practices, a group of educators generated collective responses to colonized, land-based, neoliberal conditions. Artist/pedagogue, educator, and material stories describe how inspiration and ideas were mobilized and reshaped into a context-specific ecology of practice with materials.

Key words: Reggio Emilia; pedagogy; materials; early childhood; ecology of practice; practitionerresearcher

with academics and practitioners from all over the world as we engaged in dialogue with the educational project that is Reggio Emilia.

Buoyed by the excitement and richness of experiencing the infant and toddler centres first hand, I was convinced my teaching and practice would change immediately and the whole Australian early childhood education system would travel effortlessly along with me in this inspired state. Here, in this room, sausage fat lingering, I pick up a slightly sticky bunch of plastic grapes from a container labelled "home corner" and loudly announce to the students, "Right! Tip it all out!" They look at me confused as I up-end the boxes of resources into a pile in the middle of the room. I am "busting out" these labelled materials and mixing them up. The pile becomes a mountain. Children arrive and the pile is strewn about as they rummage. Someone places a red plastic scoop onto the red table and it "disappears"- a colour hunt ensues. Children run about collecting objects to place on the corresponding coloured tables. Children are gleeful, focused, determined. Then, it happens. I notice a few children gathered at the split between the green and yellow tables. They are in serious discussion about a dinosaur toy and which table it should go on. The dinosaur has light green scales and a yellow underbelly. After much deliberation, the children carefully 
place the dinosaur on the green table with its head reaching over onto the yellow table because "it is green with a little bit of yellow." (See image below. Except where noted, photos are by the author.)
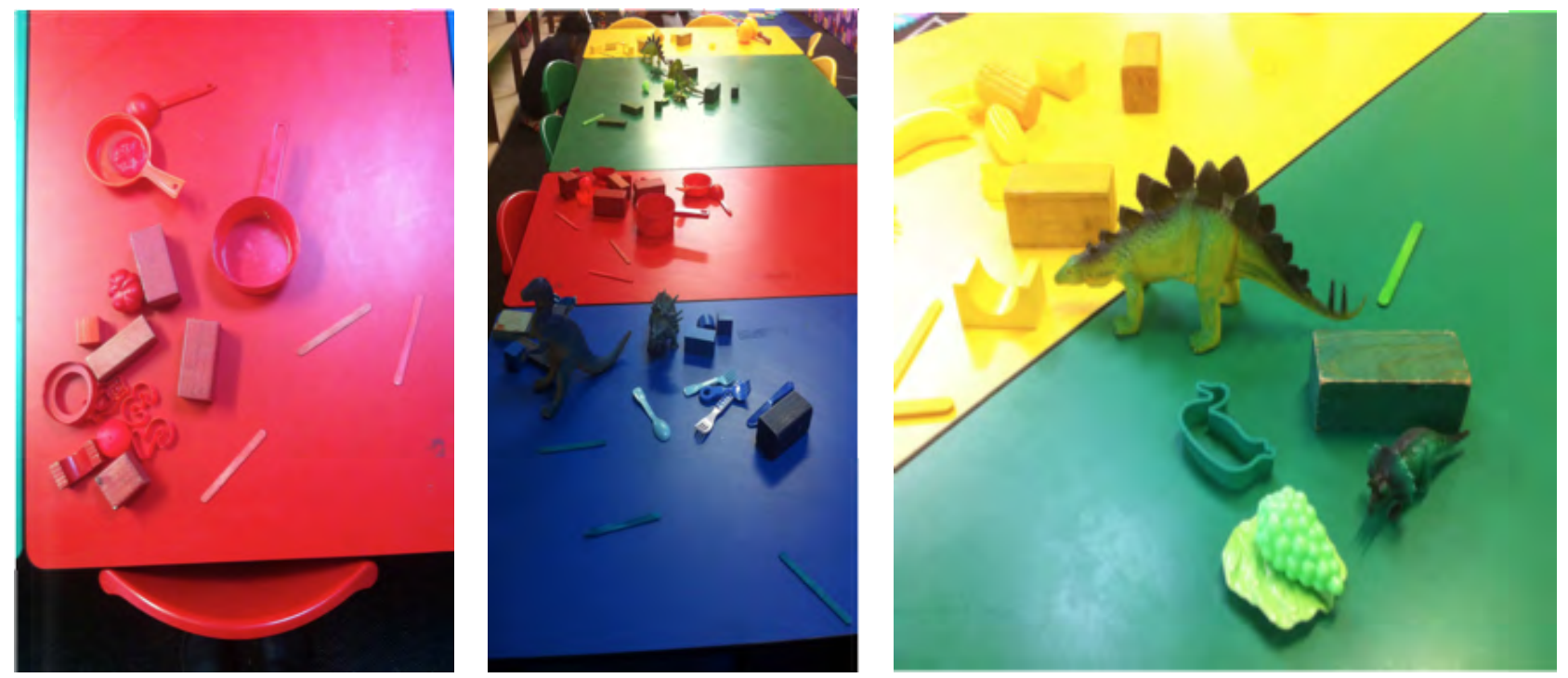

In this moment something shifts in me and I suddenly realize how materials support children's learning in multiple ways. By removing materials from their usual context and "busting them out" of the confines of their "correct" place and usage, materials become something other than categorized, preconceived inert plastic objects-developmental tools to be played with in particular ways. Here, materials offer questions. Materials generate wonderings; materials pile, stack, roll, balance, pattern, and clatter. Materials move with children in multiple ways. Materials demand that we grapple with ideas that are different from dominant early childhood ways of knowing and doing. Old, sticky plastic grapes and a green/yellow dinosaur offer a material encounter that enlivens me in an uninspiring room. Materials call us to attention, offer uncertainty, and pose questions.

\section{Studio pedagogies}

I situate myself in the Australian early childhood context as an art specialist, an educator whose arts practice informs my teaching and whose teaching informs my arts practice-materials are what I do. My interest in the Reggio Emilia approach was piqued when I learned of the role of the atelier and of the value placed on the atelierista as an artist/pedagogue who facilitates the visual languages as central to children's research. To step into the ateliers in Reggio Emilia was a fascinating and liberating experience. Guided by atelieristas, children's projects and studio processes are layered, insightful, political, and highly sophisticated and would easily sit side by side with the work of many contemporary artists. It was exciting to follow the rich makings, doings, and voices of children made visible in these dedicated studio spaces that intentionally cultivate the aesthetic experience.

My places of practice however, were a far cry from the rich, layered, and carefully cultivated aesthetic experiences of an atelier in Reggio Emilia. Unable to create a dedicated, working studio space to teach in at my university, I needed to change the way I taught the visual arts in an education setting, as well as find a place to experiment with environments and generate pedagogical questions that responded to my context and my now burgeoning material wonderings.

I began a few projects with schools and child care services to regenerate classroom spaces and activate arts-based learning opportunities for children. During this time, however, I was hyper-aware of the uptake of the Reggio 
aesthetic as a particular "look" and a marketing spiel about how services were "doing Reggio." I was not comfortable to continue this journey of generating arts projects and curricula in structures where an understanding of time, processes, and a commitment to deeper critical questions and pedagogical intentions were not valued. I was also recognizing that while the Reggio approach had sparked my thinking in ways that validated my artist-educator orientation, I was struggling with the Reggio inspiration as place to be and whether I could even remain there.

As an arts-based scholar working in the early childhood space, I take up ideas and theories through my artist lens first, then overlay ideas and questions onto early childhood research and practice. Developmental psychology has never been foregrounded in my thinking. In traditional Australian early childhood education, materials are integrated into practice as developmental tools that scaffold children's learning. Through an arts lens, I see materials differently than merely the objects that children use and make with. I attend to materials as questions, movements, and "doings." In the months following my visit to Reggio Emilia, I worked hard to translate my experience and my arts-based approach to practice in the Australian context, yet I found I was becoming increasingly frustrated by practices that positioned materials as static objects acted upon by children in early childhood classrooms. My materials thinking was now the "piling up" and vibrant movement that were generated in that stinky, overcoloured, and unloved room months before. My materials piles challenged me to rummage, to clatter about, and to search for ideas that more specifically articulated alternatives to the dominant materials discourse I was grappling with.

\section{Material Encounters: A turning point}

Around this time, my colleague travelled to Canada (September 2014) to attend a symposium (Learning How to Inherit in Colonized and Ecologically Challenged Life Worlds) that brought together scholars from a variety of different research disciplines to generate new ways of thinking, being, and doing in response to the intensifying ecological challenges of the 21st century. On her return she handed me a booklet and announced, "I think you'll like this!" I flicked through the catalogue of an exhibition, Material Encounters-a three-year arts-based research project by Canadian scholars Veronica Pacini-Ketchabaw, Sylvia Kind, and Laurie M. Kocher about materiality in early childhood where materials were positioned as encounters and events. I poured over images of children engaging with materials: clay, charcoal, paint, blocks. I read it from cover to cover. My thinking shifted deeply. Within this new encounter I felt validated as an arts-based educator. While materials are at the forefront of artsbased pedagogies, what I found was that materials discourse in education, for the most part, responded to materials as a medium to achieve a certain technique or style of "doing" as outcome. However, I could now see that materials were the process, outcome, and participants of/within practice. Collaborative researching with materials-asparticipants in practice offered me a way to activate my visual and materials sensibilities in critically responsive practices embedded in theory.

These ideas and doings generated by the Canadian scholars were something I hadn't come across before. They offered a departure from a static Euro-Western materials discourse into a common worlds conceptual framework-a framework that I could think with to translate my ideas, questions, and uncertainties about how I might be responding to the Reggio approach and the material pedagogies I was producing. A common worlds conceptual framework (Taylor \& Giugni, 2012; Pacini-Ketchabaw \& Taylor, 2015) pays attention to bringing together nature and culture, not the separation of the two. These posthuman theories influenced by Donna Haraway "focus upon the ways in which our past, present and future lives are entangled with those of other beings, non-living entities, technologies, elements, discourses, forces, landforms" (Common Worlds Research Collective, 2019).

To address dominant early childhood educational paradigms and move into other ways of thinking and doing, I use a common worlds orientation to posthuman theories as well as postdevelopmental ideas to situate my thinking and 
practice. A postdevelopmental orientation to early childhood education responds to Euro-Western developmental worldviews as being interpretive frameworks that universalize children's everyday worlds (Blaise, 2014; PaciniKetchabaw, 2011; Parnell \& Iorio, 2018). A common worlds orientation and postdevelopmental pedagogies shift away from Euro-Western developmental logics of child-centered practices and move toward complexity (PaciniKetchabaw et al., 2015) in order to generate affirmative, experimental, and responsive pedagogies. By opening up to more-than-human knowledges, these thinkings and doings work to challenge human exceptionalism and "decenter the human from the construction of knowledge" (Myers, 2015, p. 7).

By thinking with materials as more-than-human others inhabiting kindergarten spaces, I became more uncomfortable with how I was inhabiting and working with my inspirations from Reggio. While these inspirations gave me anchors for understanding, positioning, and activating my work as an arts specialist in early childhood spaces, the child-(human)centric approach within Reggio didn't seem to offer a way to respond to the posthuman ideas I was beginning to cobble together. Using common worlds ideas as a conceptual framework as well as the Material Encounters project (Pacini-Ketchabaw et al., 2014) offered me a way to respond to my Reggio inspirations in Australia. Thinking with more-than-human knowledges with materials in an Australian context poses complex questions about settler colonial narratives inscribed on Indigenous land, about resource consumption, and about environmental precarity. Thinking with more-than-human knowledges attends to settler colonial, Euro-Western material relations and was something I needed to find in order to shift from Reggio "inspired" to attuning to materials and arts-based practices within my own context, worldview, ethics, politics, and relationships. I needed to "common world" my Reggio experience in order to ask questions of and complexify my practice and to be accountable to my everyday pedagogical decisions.

\section{Finding a place to be}

Clare Court Children's Service (Clare Court) ${ }^{1}$ is an integrated service in Melbourne, Australia, that combines long day care and kindergarten within a large building surrounded by outdoor areas and gardens. Clare Court is located next to a parkland and creek. My relationship with Clare Court began as a visiting lecturer supervising preservice teachers on teaching placement at the service, then as an arts education consultant facilitating arts-based materials inquiry with a group of educators. My role as artist/pedagogue offers a rethinking of taken-for-granted materials practices in order to move into more complex pedagogical dialogues within the service.

Yet, what does complexity look like for practitioners in the everyday? What are material "doings" and how might these ideas be offered to practitioners to work with in amongst curriculum, standards, frameworks, policy, documentation, family needs, nap times, and nappy changes? What do educators do to support materials in their settings? How do materials participate with children? How are children supported to pay attention to and be present with materials? How might we begin our research by positioning materials as questions/doings/concepts? What does it mean to support materials in/with this place? How do I mobilize these ideas and material questionings and make them meaningful to the colonized, land-based, extractive, neoliberal conditions (Nxumalo, Vintimilla, \& Nelson, 2018) that influence pedagogies at Clare Court, Australia? And what specific practices, concerns, ethics, and politics are required to grapple with a more-than-human philosophy of material relationalities in this place?

Across three years, I have offered my materials inspiration through situated, responsive, collaborative everyday practices with educators and children at Clare Court. As an artist/pedagogue, I bring my own Reggio inspirations and generative thinking with materials into different classrooms at Clare Court. Through bimonthly workshops, educators participated in radical materials experimentation to unpack common worlds theories while experimenting with specific materials in a studio environment. Weekly one-on-one meetings with educators in classrooms and 
play spaces both support critical reflection on emerging materials practice(s) and theoretical understandings and generate lively, ongoing pedagogical documentation of the work. Through these ongoing processes, I've come to understand that initial Reggio-inspired provocations are made meaningful in the Clare Court context through thinking material relations as an ecology of practice. An ecology of practice in this setting is the collective cultivation of rich, situated pedagogies made up of multiple layers of concepts, ideas, knowledges, and doings with materials. This microbial thinking takes my initial troubled Reggio inspirations into the service and reshapes those ideas into a Clare-Court-specific ecology of practice with materials.

\section{Practitioner stories}

The following three stories are from educators at Clare Court, all at different stages of their careers and thinking. This core group of educators have worked with me over two to three years to rethink materials in their classrooms. These practitioner stories offer examples of how materials are thought otherwise, grappled with, piled up, and reshaped collectively with educators to animate the complexities of doing with materials as an ecology of practice. The educators are collective material thinkers activating the centre with their questioning and robust conversations about/to/with materials via art-based processes. Their collective grappling with materials has cultivated the idea of paper/cardboard relationalities as an ecology of practice that supports thinking material encounters differently. These stories show how collaborative materials research questions and conversations travel throughout the centre offering a dynamic pedagogical force for generating complexity rather than certainty.

\section{Paper interventions, by Magalie Sanassee}

Cardboard calls to paper. Cardboard offers paper to the room. Paper intervenes in educator's thinking. Paper launches into children's experience. Paper fills a room. Paper removes toys and moves furniture. Paper activates space. Paper responds to ideas. Paper offers us questions.

I have always been keen on using natural/recycled materials in my practice. As a child living in Mauritius, I remember spending hours playing with mud and drawing with chalk on every surface possible. When my dad trimmed the mango trees in the yard, he would leave all of the branches in a pile on the ground for days so my sisters and I could play through a mountain of branches and leaves. They were the best memories of my childhood. I guess I was always inclined to fall in love with materials and connect with their simplicity and complexity.

The consideration of materials as joint participants in learning (Pacini-Ketchabaw et al., 2016) is a completely new concept to me. This concept offers me a different view of looking at, understanding, and "doing" materials in the early years programs. Our sessions with Kelly set the processes in motion to question the ethicality of materials (paper/cardboard) in our classrooms and to investigate their truths. Quite honestly, I had never considered that materials owned a story or had been on a journey before landing in my world. What life did they have before? I wondered why it was essential for me to remain in question with this material. Would the experience of paper (in the classroom) affect my own?

Undertaking this work, I soon found myself in a state of cathartic realization as I began to recognize the layers of complexity living inside a tiny piece of paper. The questions that were thrown at me dazzled me completely. Where did that paper come from? Who made it? Who cut the tree it came from? Who transported it? Perhaps it was packed by someone on a different continent-what were their working conditions? Was this paper made ethically? Questioning paper almost drove me to mental exhaustion. I looked at a piece of paper in my hands-what new trajectory was I to give it now? Should I trash it or prolong its life? Paper unexpectedly became political and I started to look beyond its mere physicality. As I was getting my head around new concepts, I was also becoming 
nervous about sharing this new thinking with my colleagues. While materiality offered me new ways of celebrating materials and deepening my pedagogical insights, I became anxious about a possible rejection of this artistic inquiry by my peers. Thinking with materials in this way was so remote from developmental and child-centric theories-would my team be ready for a shift in their thinking and take on this conceptual evolution?

The beginning of our journey with materials is to gain an understanding of the materials (paper/cardboard) and think about their place in the world. We start by asking whether these materials were destined to be trashed. We wonder about whether we have a responsibility in changing their trajectory. What does it mean to engage with these materials in an ethical and sustainable way? With pedagogical support from Kelly, these "critical material questionings" guide us to shift the way we engage with materials. It is encouraging to be on this journey with my colleagues and to be able to talk to each other about our fears as well as share project ideas. I am very nervous about whether Raman, my co-room leader, will be open to these new ideas and whether she will join me on this adventure. Luckily, she is, and we begin to question paper together and invite other educators to rethink materials more intentionally. At this point, Kelly poses the question of how we as educators might support materials in our early years classroom. What do we do to help materials stay here? Cardboard and paper are repositioned in the classroom, and we question how they might be asking us to learn in different ways. We realize time is crucial for educators and our children (0-2-year olds) to settle with these new ideas and become confident to research with materials.

In our classroom, materials reinvent play and become alive in different spaces and conditions: inside, outdoors, outside in the large parklands that surround our centre, in the rain, during windy days. Day after day, we look forward to what paper and cardboard can become or do with us. During our encounters with materials, time is so crucial. The paper/cardboard offerings become more thoughtful and intentional. The coming together of materials and children starts to happen in new spaces and we witness some very intense paper-cardboard-body movements (Pacini-Ketchabaw et al., 2016). What stands out the most is how materials move through space and time. Paper and cardboard invite new ways of thinking, doing, and questioning. The materials have a force of their own-inviting the children to assemble them in so many ways. Paper and cardboard become structures, shelters, and secret places. Paper and cardboard dance, make music, travel, and move with the children and educators. During this time, we also notice there is a lot of skin-to-skin contact with materials. The child-material intimacy is reciprocal and enjoyable.

Paper tensions are also occurring along the way. Some educators question the "mess and waste," especially when we launch a 10-metre-long roll of paper into the yard. There is disapproval and it is evident that the presence of paper in the outdoor space makes some educators feel uncomfortable. Over time outside, this paper becomes inscribed with marks made by human and nonhuman (dirt, food scraps, mud, rain, footprints, birds, trees, the creek, tears, creases) and is perceived as "dirty" and "a waste of good paper" by some educators/staff. We assertively support paper to stay in the outside areas. Paper asserts itself here too, and we are shown how cardboard and paper become imprinted with our experiences as we connect more deeply with these materials.

Thinking through these material and child relations broadens our pedagogical practices and informs our thinking about children's artistic processes and learning. As I continue this work, I am generating a sense of deep care for paper. I have repositioned paper as a powerful agent that acts on me and is acted on. Paper and I join together to construct learning; we are entangled in each other's worlds and transform each other daily. I am keen to help drive this fresh pedagogical movement at our service and bring it to the children in my care. 


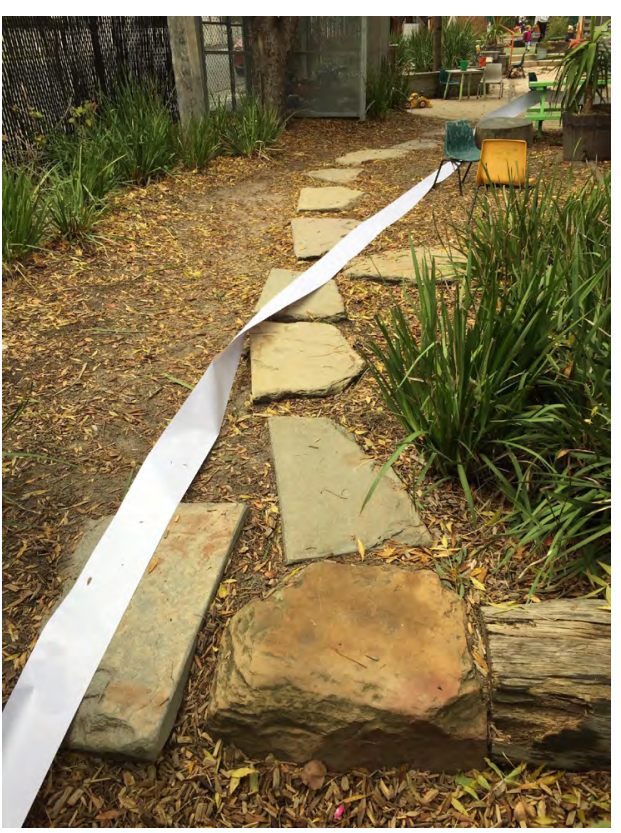

Mess and chaos, by Joanne Schloss

Children are making piles of stuff in the yard. Sandpit toys, sticks, rocksanything they find is brought together and piled up. I first notice one under the big oak tree-a pile began and then other children pitched in to build it. Over the days, piles popped up everywhere. Sometimes children interacted with the piles, but mostly it was about the gathering of stuff. Lots of educators find this activity annoying because it is difficult to pack up and is seen as pointless mess making by some.

My colleague Steph has also noticed this gathering and pile making, and is watching with interest and curiosity. We both talk about this interesting behaviour. Eventually Steph facilitates the making of a huge pile inside a truck tire we have in the yard. Cardboard tubes, branches, wood, a large board from an art easel. Children are interested, curious. They climb on, add to, take away from, and talk about the pile. Then paint shows up. I don't know who put it there, but I add brushes. Children paint. They start on the outside of the tire, then begin to lean in. They seem to want to paint every part of the pile. Some children stand back and observe their peers while others are active and get right into it. Children climb as they paint; they reach up and lean over; the branches and cardboard tubes support them. A couple of the children want to get right into the creation and stretch to reach different parts of it. The tubes and logs hold them and challenge them at the same time. Poppy comes to the pile and picks up a paintbrush. She doesn't paint the pile, she paints her face. She then holds the paintbrush above her head and slowly twirls around, painting the sky.

Viewing materials as active in children's learning and as posing questions to us has introduced me to endless creative possibilities and completely changed my view of my work. Suddenly, who I really am and the creative practice I am so passionate about is welcome. I am able to be myself and to come to work and feel challenged and excited. It feels like where I should be. I now feel free to learn with materials and children together and to engage differently with my creativity and practices of sustainability. Thinking with materials as practice has made me feel more involved, connected, and passionate about my work and has given me a deeper connection to my coworkers. Through the pedagogical facilitation and focused learning Kelly offers, I now share ideas and enthusiasm with like-minded coworkers, which gives me a new sense of purpose. My days feel more meaningful. Even though I have been working at this service for nearly 10 years, it's in the last two I have felt have the most connected and content in my job. After working for so many years in early childhood, rethinking materials in our practice and questioning materials differently has given children real autonomy, the likes of which I have not seen before. The multifaceted learning with materials supports children in so many ways-one single piece of paper can be a blanket, a cave, or a cloak. Materials invite children to imagine.

Material provocations, by Carley Rawle

Engaging in the learning sessions facilitated by Kelly on

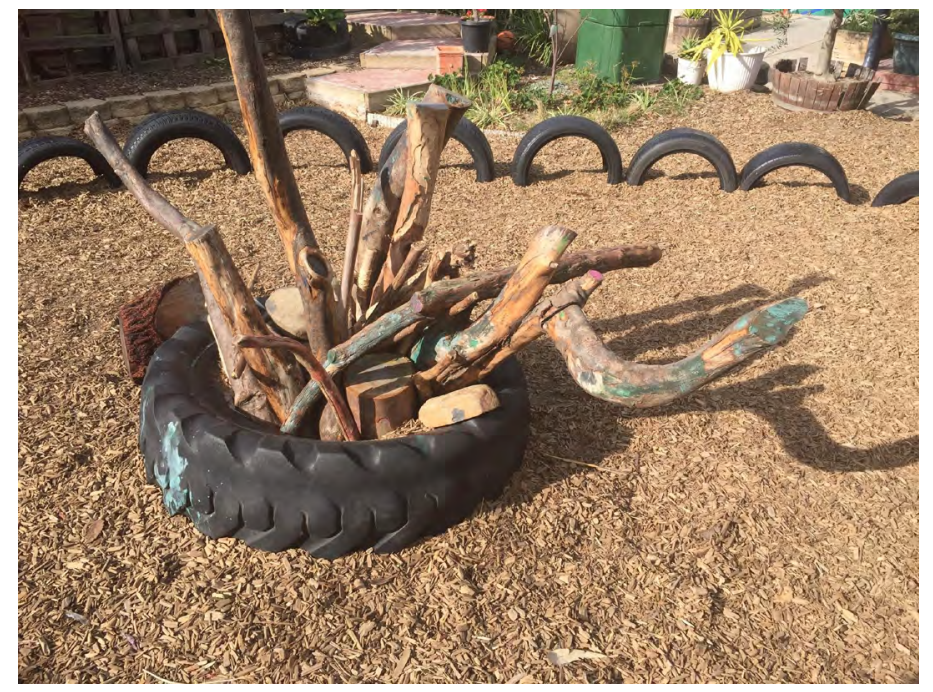


thinking with art materially, I am inspired to disrupt what is commonplace in early childhood art education. To disrupt the ongoing cycle of children engaged in teacher-directed activities understood through the lens of developmental psychology. I seek to activate moments of experimentation where materials are eventful and participatory, where ideas are unearthed in creative processes and where meaningful discourses emerge through experience. To cultivate an experimental studio space is not without risk; it requires courage, creativity, a willingness to attend to the unknown and embrace a little chaos in the flow of experience. As an artist and teacher, I am excited to push boundaries and shift how we engage in material practices in early childhood education.

I empty the art studio of all typical early childhood art resources. I roll long sheets of paper out across the floor. I travel with paper intuitively within the space, improvising where it lands as it folds, curves, and intersects around the room. Paper draws my attention to tiny alcoves and hidden spaces materializing amongst the layering. I think with paper's potential playfulness and I imagine young children and paper in relation with one another in this space. Paper pulls me in and I am curious and full of questions: What are paper's histories before it arrives ready to use in the studio? As a tree, how long did it grow for? On whose country? How do we care with/for paper? The studio is quiet. I notice paper fluttering with a passing breeze, a tiny movement activating the lively presence of nonhuman agency. How will paper and children join in and participate together in this material encounter? What connections will children receive? How will paper respond? I am captivated in this moment, in this space, attuning to and dwelling in the unknown and the energies and forces yet to entangle. I invite the children into the studio.

It has been nearly two years since I facilitated this experience and paper is continuing to move with me in multiple studio landscapes: the classroom, outdoor garden, parklands, and more. Working with Kelly throughout this time has activated socio-material practices at our centre. As educators we are more connected and we are now in dialogue with each other. The corridors of our centre are meeting places to negotiate and think through our practices. This focused and intentional pedagogical support has enlivened and influenced a group of educators to think differently, and I am wondering about how, as a community of teacher-researchers, we might think of our centre as becoming activated as an "ecology of practice."

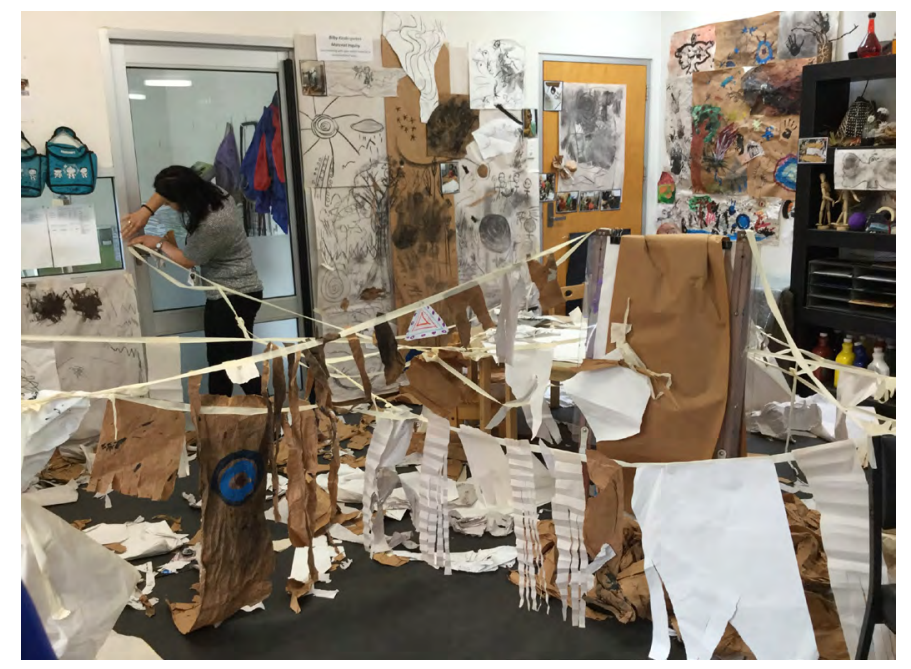

Photo by Carley Rawle.

\section{Materials as coevolutionary practice(s)}

Each of these stories shows complexity: the layered moments, questions, conditions, knowledges that entangle with materials. Each of these stories shows how educators' thinking with materials might be explained as being 
coevolutionary. Pacini-Ketchabaw, Kind, and Kocher (2016) refer to clay as an ecology. Given that ecology is defined as the study of organisms in the environment and their relationship and interrelatedness to and with each other, we might then respond to clay as soil, made up of multiple particles, minerals, and microbes-clay is living as we are living and clay responds to and with us in a variety of ways. Responding to the idea that an ecology "demand[s] that we think and feel coevolution" (Pacini-Ketchabaw et al., 2016, p. 60), Carley sees herself and her co-educatorresearchers shifting, changing, and coevolving as they are opened up to radically different ways of being in the world. Pacini-Ketchabaw et al. pose the question, "How might ecological thinking be practised in early childhood education?" (p. 60), to which Carley responds: "When I think about how the pedagogical questions you pose to us move with/in/between our practices within the centre, I cultivate an image of early childhood practitioners as in active dialogue with each other, emerging together in relation with materials, children, objects, place, and environments, inspiring each other to stay in the research and to dwell with the changing conditions that arise from day to day. Through these complex material relations, we are becoming more connected, thus, we are becoming coevolutionary."

In order to practice ecological thinking in early childhood, here, in this place full of connections, on settlercolonial-inscribed land, are educators in fact cultivating an ecology of practice? If so, how might a variety of conditions be generated to support the ecology? How might ideas, questions, processes, and materials "pile up" together? Just like the piles of old resources in the unused classroom, or the piles of mango leaves and branches from a tropical Mauritian childhood, or indeed, the piles of stuff gathered for days by children in the yard of Clare Court. What do these leaves, branches, microbes, clay, soil, paper, thoughts, pedagogical intentions, time, and critical conversations become?

\section{What next?}

Situating myself as an artist/pedagogue at Clare Court has not been without its challenges. The management and leadership team are open to and supportive of my methods, however, it has taken years of regular visits, meetings, and learning sessions to generate the relationship I now enjoy with the centre and educators. This work is ongoing. This work takes time and requires the support of teams of people who value and are willing to cultivate relationships like these and invest in generative ideas that reconceptualize practices. Through the experience of pedagogical innovation and the energy it creates, we respond to multiple questions and also tensions as we travel collectively with ideas and doings. The practitioner stories in this article show that, to be pedagogically innovative, we need to ask ourselves why we put at risk that which we have always done and how we might be accountable to doing otherwise. This work grapples with ideas about how materials might continue to support participatory and generative pedagogical practices with children. In doing this work, my risk taking for and accountability to materials practices has transformed my initial Reggio inspirations from starting-points into radical relationalities with materials in situated Australian contexts. In doing this work collectively, we cultivate an ecology of practice. 


\section{References}

Blaise, M. (2014). Interfering with gendered development: A timely intervention. International Journal of Early Childhood, 46(3), 317326. https://doi.org/10.1007/s13158-014-0122-9

Common Worlds Research Collective. (2019). About the collective. Retrieved from https://commonworlds.net/about-the-collective/

Lenz Taguchi, H. (2009). Going beyond the theory/practice divide in early childhood education: Introducing an intra-active pedagogy. London, UK: Routledge.

Myers, C. (2015). Children, among other things: Entangled cartographies of the more-than-human kindergarten classroom (Doctoral dissertation). Retrieved from https://etd.ohiolink.edu/pg_10?::NO:10:P10_ETD_SUBID:105261

Nxumalo, F., Vintimilla, C. D., \& Nelson, N. (2018). Pedagogical gatherings in early childhood education: Mapping interferences in emergent curriculum. Curriculum Inquiry, 48(4), 433-453. https://doi.org/10.1080/03626784.2018.1522930

Pacini-Ketchabaw, V. (2011). Developmental theories and child and youth care. In A. Pence \& J. White (Eds.), New perspectives in child and youth care (pp. 19-32). Vancouver: UBC Press.

Pacini-Ketchabaw, V., Kind, S., \& Kocher, L. (2016). Encounters with materials in early childhood education. London, UK: Taylor \& Francis.

Pacini-Ketchabaw, V., Kind, S., Kocher, L., Wapenaar, K., \& Kim, B. (2014). Material encounters [exhibition catalogue], Capilano University Studio Art Gallery, March 1-19.

Pacini-Ketchabaw, V., Nxumalo, F., Kocher, L., Elliot, E., \& Sanchez, A. (2015). Journeys: Complexifying early childhood practices through pedagogical narration. North York, ON: University of Toronto Press.

Parnell, W., \& Iorio, J. M. (2018). Vivid life and learning: Rendering thorough illustrations rather than chopping stories to bits. In J. M. Iorio \& W. Parnell (Eds.), Meaning making in early childhood research: Pedagogies and the personal (pp. 1-7). New York, NY: Routledge.

Taylor, A., \& Giugni, M. (2012). Common worlds: Reconceptualising inclusion in early childhood communities. Contemporary Issues in Early Childhood, 13(2), 108-119. https://doi.org/10.2304\%2Fciec.2012.13.2.108

Taylor, A., \& Pacini-Ketchabaw, V. (2015). Learning with children, ants, and worms in the Anthropocene: Towards a common world pedagogy of multispecies vulnerability. Pedagogy, Culture \& Society, 23(4), 507-529. https://doi.org/10.1080/14681366.2015. 1039050

\section{(Endnotes)}

1 Since this article was written, Clare Court Children's Services has transitioned to Gowrie Clare Court. 